\title{
A new methicillin- and gentamicin-resistant Staphylococcus aureus in Dublin: molecular genetic analysis
}

\author{
J. D. CARROLL, HARRIETT M. POMEROY, R. J. RUSSELL, J.P. ARBUTHNOTT, \\ C. T. KEANE* ORLA M. MCCORMICK and D. C. COLEMAN†
}

The Moyne Institute of Preventive Medicine, Department of Microbiology, Trinity College, Dublin 2 and 'Department of Clinical Microbiology, St James' Hospital, Dublin 8, Ireland

\begin{abstract}
Summary. In June 1985 two new strains of methicillin- and gentamicin-resistant Staphylococcus aureus (MGRSA) were isolated in a Dublin hospital. Of these, one strain spread rapidly, affecting a total of 65 patients during the following 18 months, and subsequently spread to a second Dublin hospital. Detailed laboratory studies, including plasmid screening, plasmid restriction enzyme digest pattern analysis, hybridisation analysis, location of resistance determinants, and bacteriophage typing with a set of experimental $S$. aureus typing phages, demonstrated that the "new" MGRSA organisms, termed Phenotype III Dublin isolates, were completely distinct from, and unrelated to, the MGRSA strains responsible for serious nosocomial infections in Dublin hospitals during the decade before June 1985. These Phenotype III isolates were very similar to MGRSA organisms isolated in a Baghdad hospital during 1984. Data from plasmid curing, plasmid transfer and hybridisation experiments indicated that $20 \%$ of the Phenotype-III isolates expressed chromosomally encoded, high level resistance to ethidium bromide (MIC $120 \mu \mathrm{g} / \mathrm{ml}$ ), and that this was possibly due to chromosomal integration of a penicillinase-like plasmid.
\end{abstract}

\section{Introduction}

For over a decade, isolates of methicillin- and gentamicin-resistant Staphylococcus aureus (MGRSA) have been a major cause of nosocomial infection in Dublin (Hone et al., 1981; Cafferkey et al., 1983; Dowd et al., 1983). Laboratory studies revealed that two major phenotypic groups, based on plasmid content and location of resistance determinants, could be discerned amongst isolates over the ten-year period (Cafferkey et al., 1985; Coleman et al., 1985, 1986a; Mulvey et al., 1986). Phenotype-I isolates predominated until 1978, when Phenotype-II strains became the major cause of nosocomial infection in Dublin. Phenotype-I isolates were not isolated after 1982, and PhenotypeII strains predominated as the major cause of MGRSA infection until June 1985, when a third group of MGRSA isolates was found in a single Dublin hospital from an infected patient who had recently returned to Dublin following hospitalisation in Baghdad. These organisms were non-typable

Received 21 Mar. 1988; accepted 12 June 1988.

† Correspondence should be sent to Dr D. C. Coleman. with the International Basic Set of typing phages, but could be readily differentiated from endemic Dublin Phenotype-I and -II isolates on the basis of laboratory analyses. We describe here the phenotypic and genetic characteristics of these "new" isolates, which have subsequently spread and been responsible for numerous cases of serious nosocomial infection.

\section{Materials and methods}

\section{Bacterial strains and culture conditions}

The clinical isolates of MGRSA were from nosocomial infections in one of the Federated Dublin Voluntary Hospitals between June 1985 and February 1987. Two clinical MGRSA isolates and a single methicillinresistant $S$. aureus (MRSA) isolate, all from cases of nosocomial infection during 1984, were obtained from a small Baghdad hospital. $S$. aureus strain RN4220, a derivative of strain 8325-4 (Kreiswirth et al., 1983), was used as the recipient strain in protoplast transformation experiments and as a sensitive control in antimicrobial susceptibility testing experiments. S. aureus strains SA614 and SA90 are representative Phenotype-I and Phenotype- 
II Dublin MGRSA isolates, respectively; they were used as resistant controls in antimicrobial susceptibility testing experiments (Coleman et al., 1985). Strain SA614 harboured two plasmids of $30.4 \mathrm{~kb}$ (encoding resistance to penicillin, cadmium and mercury ions, phenylmercuric acetate and ethidium bromide) and $4.3 \mathrm{~kb}$ (encoding tetracycline resistance); strain SA90 harboured two plasmids of $34.8 \mathrm{~kb}$ (encoding resistance to tetracycline, neomycin, kanamycin and ethidium bromide) and $30.4 \mathrm{~kb}$ (similar to that harboured by strain SA614).

Bacteria were grown routinely in Trypticase Soy Broth (TSB; BBL, Cockeysville, MD, USA) or LB Broth (Oxoid Ltd, Basingstoke, Hampshire). The corresponding agar media were also used.

\section{Bacteriophage typing}

Bacteriophage typing was performed as described by Blair and Williams (1961). The International Basic Set of bacteriophages for typing $S$. aureus, and experimental phages 89,90 and 92 , were supplied by the Central Public Health Laboratory, Colindale, London. Phages C2A, C6A, C7A and 932 were isolated from non-typable Irish clinical MGRSA isolates.

\section{Plasmid screening, purification and elimination}

Screening for plasmid DNA was performed by the rapid, small scale method described by Dowd et al. (1983) with the following modifications : the bacterial pellet was washed once in $1 \mathrm{ml}$ of TE buffer; after the addition of lysostaphin, the samples were incubated at $37^{\circ} \mathrm{C}$ for $30 \mathrm{~min}$; and the $\mathrm{pH}$ of the lysis buffer was adjusted to $\mathrm{pH}$ 12.42 immediately before use.

Plasmid DNA for restriction endonuclease cleavage analysis was purified from large scale $(500-\mathrm{ml})$ brothculture lysates by caesium chloride-ethidium bromide density gradient centrifugation as described by Coleman et al. (1985).

For plasmid curing experiments, isolates were cultured for $18 \mathrm{~h}$ at $42^{\circ} \mathrm{C}$, diluted, spread on agar plates, incubated at $37^{\circ} \mathrm{C}$ for $18 \mathrm{~h}$, and the resultant colonies replica plated on agar containing antibiotics or ethidium bromide, as described by Coleman et al. (1985).

\section{Preparation of total genomic DNA}

Total genomic DNA from representative clinical isolates and RN4220 transformants was prepared from exponentially growing broth cultures $(50 \mathrm{ml})$ and purified by caesium chloride density gradient centrifugation as described by Coleman et al. (1986b).

\section{Antimicrobial susceptibility testing}

Antibiotic susceptibility tests were performed by a disk diffusion method. Overnight ( $18 \mathrm{~h})$ cultures in LB broth were diluted 1 in 1000 in fresh LB broth and spread on DST agar (Oxoid). Antibiotics and other inhibitors were used at the following concentrations: penicillin $\mathrm{G}(\mathrm{Pn})$ 1.5 units; ampicillin (Ap), $25 \mu \mathrm{g}$; erythromycin (Em), $5 \mu \mathrm{g}$; lincomycin $(\mathrm{Lm}), 20 \mu \mathrm{g}$; sulphafurazole $(\mathrm{Su})$, $100 \mu \mathrm{g}$; trimethoprim (Tp), $1.25 \mu \mathrm{g}$; fusidic acid (Fu), $10 \mu \mathrm{g}$; amikacin (Ak), $30 \mu \mathrm{g}$; tetracycline (Tc), $10 \mu \mathrm{g}$; chloramphenicol $(\mathrm{Cm}), 30 \mu \mathrm{g}$; gentamicin $(\mathrm{Gm}), 10 \mu \mathrm{g}$; spectinomycin (Sp), $20 \mu \mathrm{g}$; streptomycin (Sm), $20 \mu \mathrm{g}$; kanamycin (Ka), $20 \mu \mathrm{g}$; neomycin ( $\mathrm{Ne}), 20 \mu \mathrm{g}$; vancomycin (Va), $30 \mu \mathrm{g}$; ethidium bromide (Eb), $20 \mu \mathrm{g}$; mercuric chloride $(\mathrm{Hg}), 10 \mu \mathrm{g}$; phenylmercuric acetate $(\mathrm{Pm}), 10 \mu \mathrm{g}$; and cadmium nitrate $\left.(\mathrm{Cd}), 10^{-6} \mathrm{M}\right)$.

Methicillin resistance was tested at $30^{\circ} \mathrm{C}$ with $25-\mu \mathrm{g}$ methicillin strips as described previously (Cafferkey et al., 1983). All of the isolates that expressed resistance to penicillin and ampicillin were tested for $\beta$-lactamase production by their capacity to hydrolyse the chromogenic cephalosporin nitrocefin (Oxoid) as described previously (Montgomery et al., 1979).

\section{MIC determinations}

MIC determinations for gentamicin and ethidium bromide were performed by diluting stationary-phase broth cultures 1 in $10^{4}$ and applying $c .0 .01 \mathrm{ml}\left(\right.$ c. $\left.10^{3} \mathrm{cfu}\right)$ to the surface of DST (Oxoid) agar (in the case of gentamicin) or LB agar (in the case of ethidium bromide) containing concentrations of inhibitors in the ranges $0 \cdot 1$ $1.0 \mu \mathrm{g} / \mathrm{ml}(0.1 \mu \mathrm{g} / \mathrm{ml}$ intervals $), 1.0-10.0 \mu \mathrm{g} / \mathrm{ml}(1 \mu \mathrm{g} / \mathrm{ml}$ intervals $), 10-100 \mu \mathrm{g} / \mathrm{ml}(5 \mu \mathrm{g} / \mathrm{ml}$ intervals) and 100 $200 \mu \mathrm{g} / \mathrm{ml}(10 \mu \mathrm{g} / \mathrm{ml}$ intervals $)$.

\section{Transformation}

Transformation of protoplasts of $S$. aureus strain RN4220 with purified plasmid DNA was performed by a modification of the method of Chang and Cohen (1979), as described by Dowd et al. (1983).

\section{Chemicals, antibiotics and enzymes}

Chemicals were obtained from Sigma Chemical Company Ltd (Poole, Dorset) or from BDH Chemicals Ltd (Poole, Dorset). Antibiotics and other inhibitors were obtained from Sigma. Antibiotic sensitivity disks were obtained from Oxoid and methicillin strips from Mast International Ltd (Bootle, Merseyside). Enzymes and restriction endonucleases were supplied by the Boehringer Corporation Ltd (Dublin), and used according to the manufacturer's instructions.

\section{Southern hybridisation}

DNA probes were labelled in vitro by nick-translation, as described by Rigby et al. (1977), with $20 \mu \mathrm{Ci}\left[\alpha-{ }^{32} \mathrm{P}\right]$ dATP (Amersham International plc, Buckinghamshire). Restriction endonuclease-cleaved DNA was separated by electrophoresis in $1.2 \%$ or $1.4 \% \mathrm{w} / \mathrm{v}$ agarose gels, denatured, and transferred to nitrocellulose membrane filters (Schleicher and Schull, Dassel, W. Germany) by 
the method of Southern (1975). Filters were then treated with labelled DNA probes for hybridisation under conditions of high stringency and further processed as described by Maniatis et al. (1982).

\section{Restriction endonuclease digest patterns}

Purified plasmid DNA was digested separately with the restriction endonucleases $H$ inf I, Hind III or Dde I, and the resulting fragments electrophoresed oil agarose $1.4 \% \mathrm{w} / \mathrm{v}$ or polyacrylamide $5 \% \mathrm{w} / \mathrm{v}$ gels as described by Coleman and Foster (1981).

\section{Results}

In June 1985, two "new" strains of MGRSA were isolated from a patient in a Dublin hospital who had recently returned to Dublin following hospitalisation in Baghdad. One of these strains spread rapidly, affecting a total of 65 patients between June 1985 and February 1987. We describe here the characterisation of these "new" MGRSA organisms, termed Phenotype-III isolates, and compare their properties with similar isolates from a Baghdad hospital and with representative Phenotype-I and Phenotype-II Dublin MGRSA strains.

\section{Bacteriophage typing}

A total of 67 Phenotype-III isolates from 65 patients were included in the study, all of which were non-typable with the International Basic Set of typing phages, but which were typable with several "experimental phages". These represented $39 \%$ of the total MGRSA isolates from the hospital during the study period, the remainder were endemic Phenotype-II isolates. Of the PhenotypeIII isolates, 65 had the experimental phage-typing pattern C6A/89/92/932 at 100X RTD (Routine Test Dilution), as did the two Baghdad MGRSA isolates (table I). Two of the Phenotype-III strains, which were isolated from the index patient and not subsequently, and the single Baghdad MRSA isolate, were typable with experimental phage 89 only (table I). Eighty-one Phenotype-II isolates from individual patients in the same hospital during the study period, which were non-typable with the International Basic Set of typing phages, exhibited experimental phage-typing patterns which were distinct from those of the Phenotype-III isolates (table I).

\section{Plasmid screening}

The three Baghdad isolates and 49 of the 67 novel Dublin Phenotype-III isolates were screened for the presence of plasmid DNA. All of the clinical isolates tested harboured a plasmid of $3.2 \mathrm{~kb}$, and the vast majority harboured a second plasmid of $2.8 \mathrm{~kb}$ (table I). One of the Dublin type- 89 isolates, one of the Baghdad type-C6A/89/92/932 isolates, and the single Baghdad type- 89 strain, harboured a third plasmid of $2.2 \mathrm{~kb}$ (table I). However, this plasmid was only detected in a minority of plasmid screening experiments with broth cultures inoculated from individual colonies of these strains, and was readily lost in the absence of ethidium bromide selection.

No large plasmids $(\geqslant 30 \mathrm{~kb}$ ) were detected in any of the isolates tested. The same screening procedure readily detected large plasmids in the representative Dublin Phenotype-I and -II MGRSA isolates SA614 and SA90 which harboured plasmids of $30.4 \mathrm{~kb}$ and $4.3 \mathrm{~kb}$ (SA614), and $30.4 \mathrm{~kb}$ and $34.8 \mathrm{~kb}$ (SA90), respectively (table I). The possibility that the presence of large plasmids in the Phenotype-III or Baghdad. isolates was masked by chromosomal DNA bands following electrophoresis in agarose gels was considered unlikely, since no large plasmids were identified in these strains during preparative plasmid DNA isolation, whereas the large plasmids of isolates SA614 and SA90 were readily recognised.

\section{Antimicrobial agent susceptibility testing}

The 67 Dublin Phenotype-III isolates and the three Baghdad isolates were tested for susceptibility to antimicrobial agents. All the clinical isolates were resistant to penicillin, ampicillin, methicillin, aminoglycosides, tetracycline, erythromycin, mercuric chloride, phenylmercuric acetate and cadmium nitrate. They were all susceptible to fusidic acid, trimethoprim and vancomycin (table I). When MIC determinations were performed on representative ethidium bromide-resistant $\left(\mathrm{Eb}^{\mathrm{r}}\right)$ isolates of both phage types, two distinct levels of $\mathrm{Eb}^{\mathrm{r}}$ were detected (table II). The C6A/89/92/932 PhenotypeIII isolate SA84 expressed a four-fold higher level of $\mathrm{Eb}^{\mathrm{r}}(\mathrm{MIC} 120 \mu \mathrm{g} / \mathrm{ml})$ than did the Baghdad typeC6A/89/92/932 isolate SA110 (MIC $30 \mu \mathrm{g} / \mathrm{ml}$ ). All other $\mathrm{Eb}^{\mathrm{r}}$ Dublin Phenotype-III isolates of this phage type tested (eight isolates) exhibited ethidium bromide MIC values similar to strain SA84, and this level of resistance was termed high level ethidium bromide resistance $\left(\mathrm{Eb}^{\mathrm{h}}\right.$, table II). The $\mathrm{Eb}^{\mathrm{r}}$ type 89 strains expressed low level ethidium bromide resistance $\left(\mathrm{Eb}^{l} ; \mathrm{MIC} 30 \mu \mathrm{g} / \mathrm{ml}\right)$, as did the Baghdad type-C6A/89/92/932 strain SA110 (table II).

The MIC of gentamicin was also determined for 
Table I. Properties of methicillin-and gentamicin-resistant $S$. aureus strains from Dublin and comparison with strains from Baghdad

\begin{tabular}{|c|c|c|c|c|c|c|c|}
\hline \multirow[b]{2}{*}{$\begin{array}{l}\text { Source and strain } \\
\text { designation }\end{array}$} & \multirow[b]{2}{*}{$\begin{array}{l}\text { Pheno- } \\
\text { type }\end{array}$} & \multirow{2}{*}{$\begin{array}{l}\text { Experimental } \\
\text { phage type }\end{array}$} & \multirow{2}{*}{$\begin{array}{l}\text { Number } \\
\text { of isolates } \\
\text { tested }\end{array}$} & \multicolumn{2}{|c|}{ Location of resistance determinants } & \multirow{2}{*}{$\begin{array}{l}\text { Plasmid } \\
\text { content } \\
(\mathrm{kb})\end{array}$} & \multirow{2}{*}{$\begin{array}{c}\text { Number of } \\
\text { strains car } \\
\text { rying plas- } \\
\text { mid* }\end{array}$} \\
\hline & & & & Chromosome & Plasmid & & \\
\hline Dublin Hospital & III & C6A/89/92/932 & 65 & $\begin{array}{l}\mathrm{Ap}, \mathrm{Pn}, \mathrm{Me}, \mathrm{Gm}^{3}, \mathrm{Km}, \mathrm{Ne}, \mathrm{Tc} \\
\mathrm{Su}, \mathrm{Em}, \mathrm{Sm}, \mathrm{Sp}, \mathrm{Eb}^{\mathrm{h}}+, \mathrm{Hg}, \mathrm{Pm} \text {, } \\
\text { Cd, }\end{array}$ & $\begin{array}{l}\text { cryptic } \\
\mathrm{Cm}\end{array}$ & $\begin{array}{l}3 \cdot 2 \\
2 \cdot 8\end{array}$ & $\begin{array}{l}47 \\
42\end{array}$ \\
\hline \multirow[t]{2}{*}{ Dublin Hospital } & III & 89 & 1 & $\begin{array}{l}\mathrm{Ap}, \mathrm{Pn}, \mathrm{Me}, \mathrm{Gm}^{2}, \mathrm{Km}, \mathrm{Ne}, \mathrm{Tc} \\
\mathrm{Lm}, \mathrm{Em}, \mathrm{Sm}, \mathrm{Sp}, \mathrm{Hg}, \mathrm{Pm}, \mathrm{Cd}\end{array}$ & $\begin{array}{l}\text { cryptic } \\
\mathrm{Cm}^{1} \\
\mathrm{~Eb}^{1}\end{array}$ & $\begin{array}{l}3 \cdot 2 \\
2 \cdot 8 \\
2 \cdot 2\end{array}$ & $\begin{array}{l}3 \\
3 \\
1 \ddagger\end{array}$ \\
\hline & & 89 & 1 & $\begin{array}{l}\text { Ap, } \mathrm{Pn}, \mathrm{Me}, \mathrm{Gm}^{4}, \mathrm{Km}, \mathrm{Ne}, \mathrm{Tc} \\
\mathrm{Em}, \mathrm{Sm}, \mathrm{Sp}, \mathrm{Hg}, \mathrm{Pm}, \mathrm{Cd}\end{array}$ & $\begin{array}{l}\text { cryptic } \\
\mathrm{Cm}\end{array}$ & $\begin{array}{l}3 \cdot 2 \\
2 \cdot 8\end{array}$ & $\begin{array}{l}1 \\
1\end{array}$ \\
\hline \multirow[t]{2}{*}{ Baghdad Hospital } & - & $\mathrm{C} 6 \mathrm{~A} / 89 / 92 / 932$ & 2 & $\begin{array}{l}\mathrm{Ap}, \mathrm{Pn}, \mathrm{Me}, \mathrm{Gm}^{1}, \mathrm{Km}, \mathrm{Ne}, \mathrm{Tc} \\
\mathrm{Su}, \mathrm{Em}, \mathrm{Sm}, \mathrm{Sp}, \mathrm{Hg}, \mathrm{Pm}, \mathrm{Cd}\end{array}$ & $\begin{array}{l}\text { cryptic } \\
\mathrm{Cm} \\
\mathrm{Eb}^{1}\end{array}$ & $\begin{array}{l}3 \cdot 2 \\
2 \cdot 8 \\
2 \cdot 2\end{array}$ & $\begin{array}{l}1 \\
2 \\
1 \ddagger\end{array}$ \\
\hline & - & 89 & 1 & $\begin{array}{l}\mathrm{Ap}, \mathrm{Pn}, \mathrm{Me}, \mathrm{Km}, \mathrm{Ne}, \mathrm{Tc}, \mathrm{Su} \\
\mathrm{Em}, \mathrm{Sm}, \mathrm{Sp}, \mathrm{Hg}, \mathrm{Pm}, \mathrm{Cd}\end{array}$ & $\begin{array}{l}\text { cryptic } \\
\mathrm{Cm}^{1} \\
\mathrm{~Eb}^{1}\end{array}$ & $\begin{array}{l}3 \cdot 2 \\
2 \cdot 8 \\
2 \cdot 2\end{array}$ & $\begin{array}{l}1 \\
1 \\
1\end{array}$ \\
\hline $\begin{array}{l}\text { Dublin Hospital } \\
\text { strain SA614 }\end{array}$ & I & Not tested & $-\S$ & $\mathrm{Me}, \mathrm{Gm}^{5}, \mathrm{Km}, \mathrm{Ak}, \mathrm{Sm}, \mathrm{Sp}$ & $\begin{array}{l}\mathrm{Pc}, \mathrm{Cd}, \mathrm{Hg} \\
\mathrm{Pm}, \mathrm{Eb}^{\mathrm{h}} \\
\mathrm{Tc}\end{array}$ & $\begin{array}{r}30 \cdot 4 \\
4 \cdot 3\end{array}$ & $\begin{array}{l}- \\
-\end{array}$ \\
\hline $\begin{array}{l}\text { Dublin Hospital } \\
\text { strain SA90 }\end{array}$ & II & C7A" & $-\S$ & $\mathrm{Me}, \mathrm{Gm}^{1}, \mathrm{Km}, \mathrm{Sm}, \mathrm{Sp}, \mathrm{Fu}$ & $\begin{array}{l}\mathrm{Pc}, \mathrm{Cd}, \mathrm{Hg}, \\
\mathrm{Pm}_{\mathrm{h}}, \mathrm{Eb}^{\mathrm{h}} \\
\mathrm{Tc}, \mathrm{Km}, \mathrm{Ne}, \\
\mathrm{Eb}\end{array}$ & $\begin{array}{l}30 \cdot 4 \\
34 \cdot 8\end{array}$ & $\begin{array}{l}- \\
-\end{array}$ \\
\hline
\end{tabular}

$\mathrm{Ak}$, amikacin; $\mathrm{Ap}$, ampicillin; $\mathrm{Cd}$, cadmium nitrate; $\mathrm{Cm}$, chloramphenicol; $\mathrm{Em}$, erythromycin; $\mathrm{Eb}^{\text {h }}$, high level ethidium bromide resistance (MIC $120 \mu \mathrm{g} / \mathrm{ml}$ ); Eb', low level ethidium bromide resistance (MIC $30 \mu \mathrm{g} / \mathrm{ml}$ ); $\mathrm{Gm}^{\mathrm{s}}$, High level gentamicin resistance (MIC $150 \mu \mathrm{g} / \mathrm{ml}$ ); $\mathrm{Gm}^{4}$, high level gentamicin resistance (MIC $120 \mu \mathrm{g} / \mathrm{ml}$ ); $\mathrm{Gm}^{3}$, intermediate level gentamicin resistance (MIC $55 \mu \mathrm{g} / \mathrm{ml}$ ); $\mathrm{Gm}^{2}$, intermediate level gentamicin resistance (MIC $30 \mu \mathrm{g} / \mathrm{ml}$ ); $\mathrm{Gm}^{1}$, low level gentamicin resistance (MIC $10 \mu \mathrm{g} / \mathrm{ml}$ ); $\mathrm{Hg}$, mercuric chloride; Km, kanamycin; Lm, lincomycin; Me, methicillin; Pm, phenylmercuric acetate; Pn, penicillin G; Sm, streptomycin, Sp, spectinomycin; Su, sulphafurazole; Tc, tetracycline.

$\dagger$ High level ethidium bromide resistance was observed in $20 \%$ of the tested Dublin isolates of phage type C6A/89/92/932.

$\ddagger$ In the strains where the plasmid of $2.2 \mathrm{~kb}$ was observed, only a minority of the individual colonies were found to harbour the plasmid.

*All the type-89 isolates, both the Baghdad type-C6A/89/92/932 strains, and 47 of the 65 Dublin type-C6A/89/92/932 isolates were screened.

"The 81 Phenotype-II MGRSA isolates obtained during the study period from the same Dublin hospital, and which were nontypable with the International Basic Set of typing phages, were grouped into experimental phage types as follows: $\mathrm{C} 7 \mathrm{~A}, 28$ isolates; 92, 32 isolates; $\mathrm{C} 2 \mathrm{~A} / \mathrm{C} 6 \mathrm{~A} / \mathrm{C} 7 \mathrm{~A} / 92 / 932,21$ isolates.

§ Isolates SA614 and SA90 are representative Phenotype-I and -II Dublin MGRSA strains.

representative clinical isolates, cured derivatives and RN4220 transformants harbouring plasmids from clinical strains. Several distinct gentamicin resistance $\left(\mathrm{Gm}^{\mathrm{r}}\right)$ levels were detected. All of the Dublin C6A/89/92/932 isolates tested (10 isolates) expressed a gentamicin MIC value of $55 \mu \mathrm{g} / \mathrm{ml}$ (table II), whereas the two Baghdad isolates of this phage type expressed a five-fold lower level of $\mathrm{Gm}^{\mathrm{r}}$, similar to that expressed by the representative Phenotype-II Dublin isolate SA90 (MIC $10 \mu \mathrm{g} / \mathrm{ml}$; table II). One of the two Dublin type-89 isolates expressed $\mathrm{Gm}^{\mathrm{r}}$ at a level intermediate between the Dublin and Baghdad type-C6A/89/92/932 strains
(MIC $30 \mu \mathrm{g} / \mathrm{ml}$ ), whereas the remaining Dublin type-89 isolate SA663 expressed a high level of $\mathrm{Gm}^{\mathrm{r}}$ (MIC $120 \mu \mathrm{g} / \mathrm{ml}$; table II). This latter isolate was the only one of the two Dublin type-89 strains that did not express resistance to lincomycin (table I). The representative Phenotype-I Dublin isolate SA614 expressed the highest level of $\mathrm{Gm}^{\mathrm{r}}$ of all the strains tested (MIC $150 \mu \mathrm{g} / \mathrm{ml}$ ).

\section{Localisation of resistance determinants}

Representative Dublin strains of phage type C6A/89/92/932 tested (eight isolates) were readily 
cured of high level ethidium bromide resistance $\left(\mathrm{Eb}^{\mathrm{h}}\right)$ with an efficiency of approximately $95 \%$, when the isolates were cultured in broth at $42^{\circ} \mathrm{C}$ for $18 \mathrm{~h}$. Spontaneous curing of the $\mathrm{Eb}^{\mathrm{h}}$ phenotype was detected at a frequency of approximately $40 \%$ (i.e., four of ten colonies tested were found to have lost the $\mathrm{Eb}^{\mathrm{h}}$ marker) when the isolates were sub-cultured in broth at $37^{\circ} \mathrm{C}$ for $18 \mathrm{~h}$. Loss of $\mathrm{Eb}^{\mathrm{h}}$ was not associated with plasmid loss (table II). Furthermore, four representative isolates expressing $E b^{h}$, cultured in Eb-containing media to select for the retention of the marker, exhibited plasmid profiles and plasmid band intensities in agarose gels indistinguishable from the isolates cultured without Eb selection, and with derivatives which no longer expressed the $E b^{h}$ phenotype. These findings suggested that the $\mathrm{Eb}^{\mathrm{h}}$ phenotype in the isolates tested was not due to detectable amplification of plasmid DNA sequences under Eb selection. Loss of low level ethidium bromide resistance $\left(\mathrm{Eb}^{\mathrm{l}}\right)$ by the three clinical isolates which expressed this phenotype was correlated with the loss of a plasmid of $2.2 \mathrm{~kb}$ (table II). Chloramphenicol resistance $\left(\mathrm{Cm}^{\mathrm{r}}\right)$ was cured at a frequency of approximately $10 \%$ from the strains tested (eight Dublin and two Baghdad type-C6A/89/92/932 isolates and all the type-89 strains) after growth in broth at $42^{\circ} \mathrm{C}$ for $18 \mathrm{~h}$, and loss of the $\mathrm{Cm}^{\mathrm{r}}$ marker was correlated with the loss of a plasmid of $2 \cdot 8 \mathrm{~kb}$.

Confirmation of the above findings was obtained by transforming purified plasmid DNA from representative clinical strains into $S$. aureus strain RN4220. When plasmid DNA from the Dublin clinical isolate SA360 (type C6A/89/92/932) was used to transform strain RN4220, $\mathrm{Cm}^{\mathrm{r}}$ transformants were readily isolated, and approximately $80 \%$ of those tested harboured a single plasmid of $2.8 \mathrm{~kb}$, whereas $20 \%$ were found to harbour an additional plasmid of $3 \cdot 2 \mathrm{~kb}$. Similar results were obtained with purified plasmid DNA from eight other clinical isolates from the Dublin and Baghdad hospitals. Susceptibility testing experiments demonstrated that the transformant derivatives had acquired $\mathrm{Cm}^{\mathrm{r}}$ only.

Table II. MICs of ethidium bromide and gentamicin for clinical isolates and derivatives

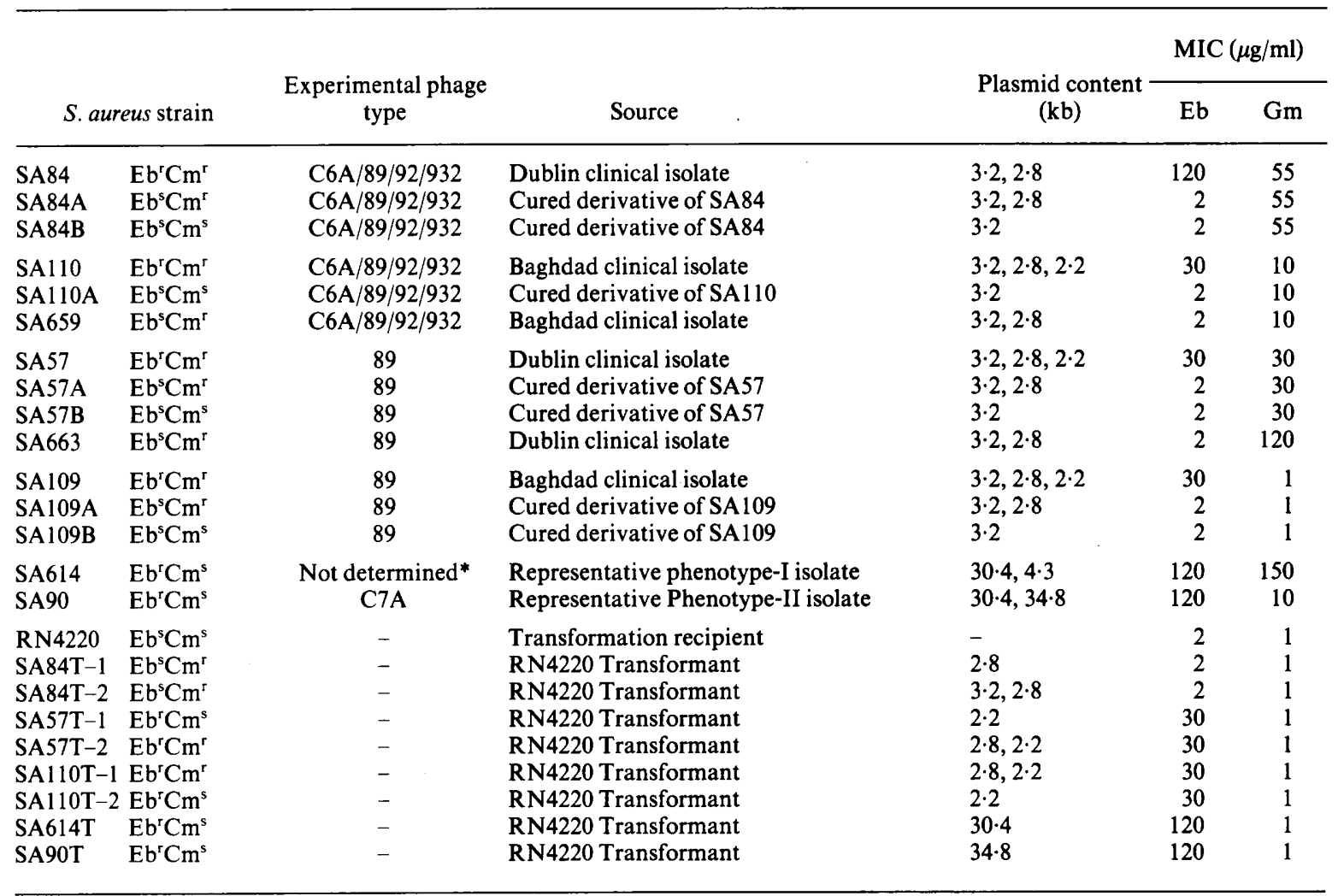

* The Phenotype-I MGRSA isolate SA614 was typable with phage 85 of the International Basic Set of typing phages. 
No known phenotype could be ascribed to the plasmids of $3.2 \mathrm{~kb}$, and it is likely that the $\mathrm{Cm}^{\mathrm{r}}$ transformants harbouring both the $\mathrm{Cm}^{\mathrm{r}}$ plasmids and the larger cryptic plasmids arose by cotransformation events.

Ethidium bromide-resistant transformants of RN4220 were isolated only when plasmid DNA from the three clinical strains harbouring plasmids of $2.2 \mathrm{~kb}$ was used as the transforming DNA. These $E b^{r}$ derivatives expressed the $E b^{1}$ phenotype (table II) and, of representative transformants tested, all were found to harbour a plasmid of $2 \cdot 2 \mathrm{~kb}$, of which approximately $10 \%$ harboured an additional plasmid of $2.8 \mathrm{~kb}$, and expressed $\mathrm{Cm}^{\mathrm{r}}$.

Plasmids of $4.3 \mathrm{~kb}$ and $34.8 \mathrm{~kb}$ harboured by the representative Phenotype-I and Phenotype-II isolates SA614 and SA90, respectively, were readily cured at frequencies of approximately $60 \%$ after the organisms were cultured at $42^{\circ} \mathrm{C}$. However, the penicillinase plasmids of $30.4 \mathrm{~kb}$, also harboured by these isolates, proved difficult to cure and were only eliminated at a frequency of approximately $0.01 \%$. However, purified preparations of all these plasmids transformed protoplasts of $S$. aureus strain RN4220 at high efficiency.

In the light of the data from curing and transformation experiments, it is likely, therefore, that apart from the $\mathrm{Cm}^{\mathrm{r}}$ and $\mathrm{Eb}^{1}$ markers, all the other resistance determinants were chromosomally encoded in both the Dublin Phenotype-III and Baghdad clinical isolates.
Restriction enzyme digest patterns and hybridisation analysis of plasmid DNA

Restriction endonuclease digests of representative plasmids of $3.2 \mathrm{~kb}, 2.8 \mathrm{~kb}$ and $2.2 \mathrm{~kb}$, from clinical isolates of phage types $\mathrm{C} 6 \mathrm{~A} / 89 / 92 / 932$ and 89, from both Dublin and Baghdad, yielded characteristic restriction fragment patterns when cleaved with the endonuclease Dde I (fig. 1). However, in all cases tested, plasmids of similar size yielded indistinguishable fragment patterns, regardless of their origin. Similar results were obtained when the restriction endonucleases Hind III and Hinf I were used to cleave plasmid DNA (data not shown). To further establish the degree of relatedness between plasmids of similar size from isolates from both centres, and to determine whether the three types of plasmids detected in the clinical isolates shared any extensive sequence homology, hybridisation experiments were performed. Representative plasmids of $3.2 \mathrm{~kb}, 2.8 \mathrm{~kb}$ and $2 \cdot 2 \mathrm{~kb}$ were radioactively labelled with ${ }^{32} \mathrm{P}$, by nick-translation, and used separately as genetic probes in hybridisation experiments with Dde Ifragmented plasmids from clinical isolates, under conditions of high stringency. When plasmids of similar size were digested with $D d e$ I and probed with ${ }^{32}$ P-labelled representative plasmids of the same size, indistinguishable homology patterns were detected in each case (fig. 1). These results demonstrated that plasmids of similar size, from both the Baghdad and Dublin hospital isolates, had

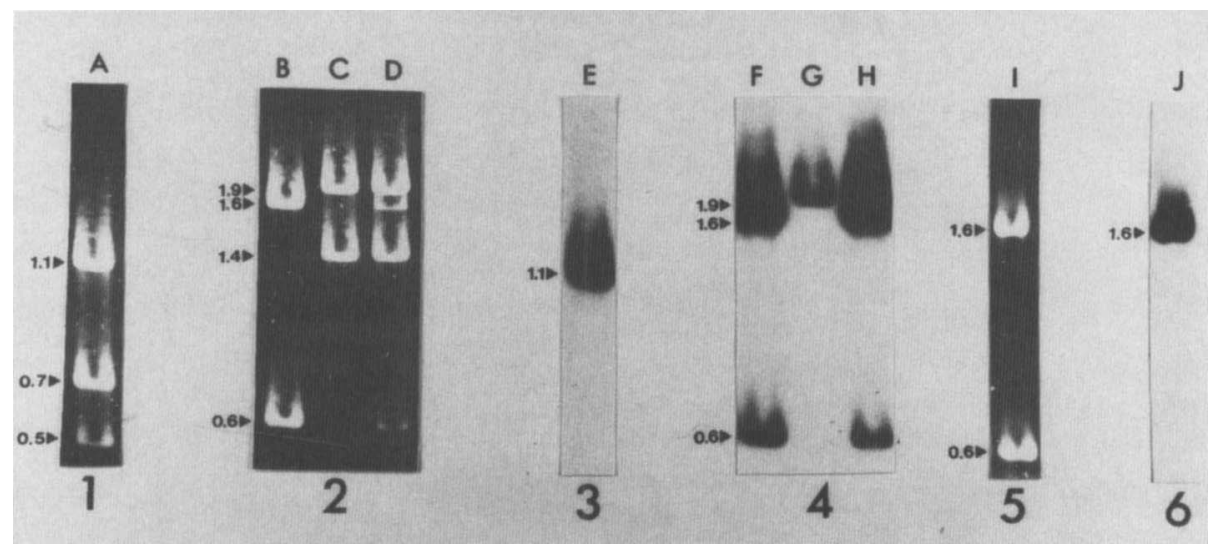

Fig. 1. Restriction enzyme digest patterns and hybridisation analysis of plasmid DNA from clinical $S$. aureus isolates. Panels 1, 2, and 5: restriction endonuclease $D d e$ I-generated fragments of plasmid DNA-track A, plasmid of $2 \cdot 2 \mathrm{~kb}$ from strain SA110 (Baghdad, type C6A/89/92/932); B, plasmid of $2.8 \mathrm{~kb}$ from strain SA84 (Dublin, type C6A/89/92/932); C, plasmid of $3.2 \mathrm{~kb}$ from strain SA57 (Dublin, type 89); D, plasmids of 2.8 and $3.2 \mathrm{~kb}$ from strain SA84; I, plasmid of $2.8 \mathrm{~kb}$ from strain SA659 (Baghdad, type C6A/89/92/932). Panels 3 and 4: autoradiogram of the material shown in panels 1 and 2 after hybridisation with the ${ }^{32} \mathrm{P}$ labelled $\mathrm{Cm}^{\mathrm{T}}$ plasmid of $2.8 \mathrm{~kb}$ from strain SA84. Panel 6: autoradiogram of the material contained in panel 5 after hybridisation with the ${ }^{32} \mathrm{P}$-labelled $\mathrm{Eb}^{1}$ plasmid of $2 \cdot 2 \mathrm{~kb}$ from strain SA110. The sizes $(\mathrm{kb})$ of the plasmid DNA fragments and the hybridisation bands respectively, are indicated on the left of each panel. 
very similar structures, were homologous under conditions of high stringency, and, therefore, were likely to be closely related.

However, representative plasmids of $3.2 \mathrm{~kb}$ and $2 \cdot 2 \mathrm{~kb}$, and of $3 \cdot 2 \mathrm{~kb}$ and $2 \cdot 8 \mathrm{~kb}$ were only partially homologous with the $\mathrm{Cm}^{\mathrm{r}}$ and $\mathrm{Eb}^{\mathrm{r}}$ plasmid probes, respectively (fig. 1). Single homologous fragments of $1.9 \mathrm{~kb}$ and $1.16 \mathrm{~kb}$, respectively, were detected when the $\mathrm{Cm}^{\mathrm{r}}$ plasmid probe was used to hybridise DdeI-generated fragments of plasmids of $3.2 \mathrm{~kb}$ and $2 \cdot 2 \mathrm{~kb}$. A single homologous fragment of $1.6 \mathrm{~kb}$, and two homologous fragments of $1.9 \mathrm{~kb}$ and $1.34 \mathrm{~kb}$ were detected when the $\mathrm{Eb}^{\mathrm{r}}$ plasmid probe was hybridised with $D d e$ I-fragmented plasmids of $3.2 \mathrm{~kb}$ and $2.8 \mathrm{~kb}$, respectively. These findings demonstrated that the three types of plasmids found in both the Dublin and Baghdad clinical isolates, although distinguishable from each other as evidenced by heterogeneity in the location of restriction sites, differences in size and associated phenotype, shared extensive DNA homology with each other under conditions of high stringency.

\section{Hybridisation analysis of chromosomal DNA}

Data from curing and plasmid transfer experiments, described above, suggested that the "new" Dublin Phenotype-III MGRSA isolates and the related Baghdad isolates harboured chromosomally located resistance determinants to penicillin, phenylmercuric acetate, cadmium and mercury ions, and in the case of a proportion of the Dublin $\mathrm{C} 6 \mathrm{~A} / 89 / 92 / 932$ isolates, high level resistance to ethidium bromide. These resistance markers were invariably located on large penicillinase plasmids in the endemic Dublin MGRSA isolates and in MGRSA strains from many other centres (Townsend et al., 1987).

Hybridisation experiments were performed on two representative clinical isolates with the entire penicillinase plasmid $(30.4 \mathrm{~kb})$ from the endemic Phenotype-II MGRSA Dublin strain, SA90, as a genetic probe. Total genomic DNA from the plasmid-free, laboratory control strain RN4220, and the type C6A/89/92/932 clinical strains SA84 and SA659, from Dublin and Baghdad respectively, was cleaved separately with the restriction endonucleases $B g l \mathrm{I}$ and $P s t \mathrm{I}$, and with a combination of these two enzymes, and hybridised with the ${ }^{32} \mathrm{P}$ labelled penicillinase plasmid probe.

Extensive sequence homology was detected with the DNA samples from both clinical strains (fig. 2), and, furthermore, the patterns of homologous restriction fragments detected with both DNA samples were very similar, regardless of the restric- tion enzyme(s) used (fig. 2). No homology was detected with the DNA sample from the control $S$. aureus strain RN4220. These results indicated that both the "new" Dublin MGRSA isolates, and the similar Baghdad organisms, harboured integrated penicillinase plasmid DNA sequences in their respective chromosomal DNAs.

\section{Discussion}

Detailed laboratory analysis of the recent Phenotype-III MGRSA isolates demonstrated that they were distinct from the endemic Dublin PhenotypeI and -II MGRSA organisms. The plasmid content of the Phenotype-III isolates was completely different from that of the endemic Dublin Phenotype-I and -II MGRSA strains isolated in the decade prior

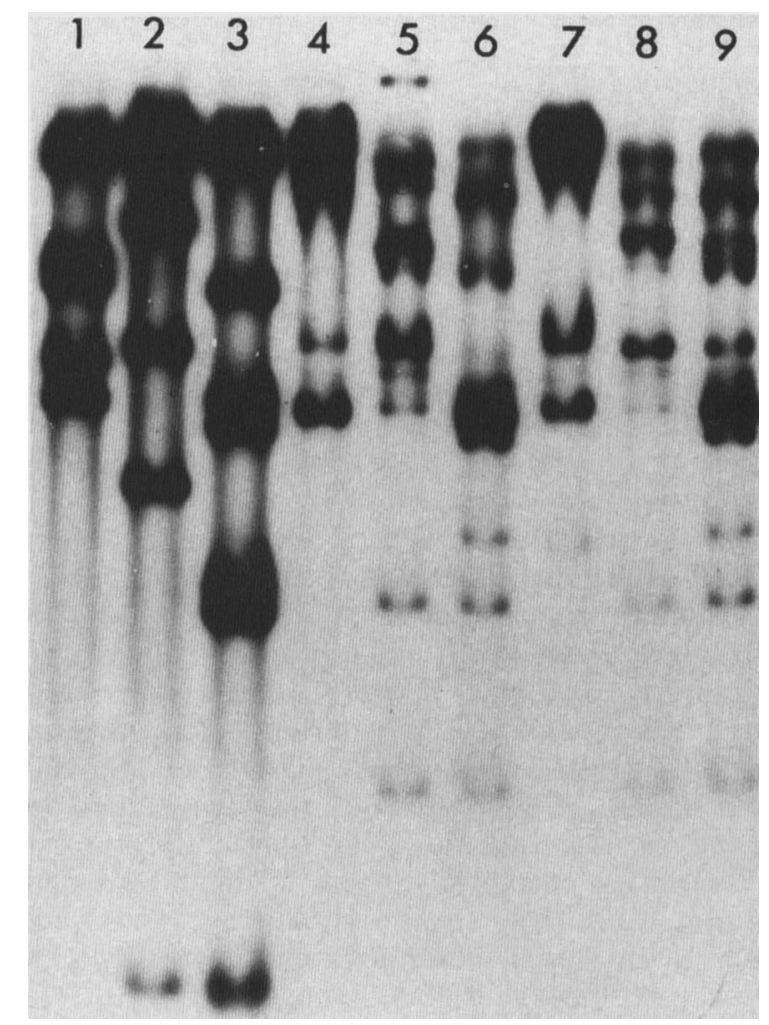

Fig. 2. Autoradiogram of total genomic DNA from representative Dublin and Baghdad clinical isolates, after hybridisation with the ${ }^{32} \mathrm{P}$-labelled penicillinase plasmid of $30.4 \mathrm{~kb}$ from the Dublin Phenotype-II MGRSA strain SA90. Tracks 1-3: hybridisation patterns of digested penicillinase plasmid DNA from strain SA90; tracks 4-6 and 7-9: hybridisation patterns of digested total genomic DNA of the representative Dublin Phenotype-III and Baghdad clinical strains SA84 and SA659, respectively. The DNA samples corresponding to tracks 1,4 and 7 were cleaved with $P$ st I; tracks 2, 5, and 8, with $B g l \mathrm{I}$; and tracks 3, 6, and 9, with a combination of $B g l \mathrm{I}$ and $P s t \mathrm{I}$. 
to June 1985 (table I). Furthermore, all of the Phenotype-III isolates were sensitive to fusidic acid, a feature characteristic of the Phenotype-I Dublin strains, which have not been isolated in Dublin since 1982 (Coleman et al., 1985; Mulvey et al., 1986). However, the Phenotype-III isolates did share some features in common with Phenotype-I and -II Dublin isolates. Of representative isolates examined, all expressed chromosomal resistance to methicillin, gentamicin, erythromycin, kanamycin, streptomycin and spectinomycin. However, the Phenotype-III MGRSA isolates apparently also expressed chromosomal resistance to penicillin, cadmium and mercury ions, phenylmercuric acetate, neomycin and tetracycline; resistance markers that were invariably plasmid encoded in the endemic Dublin MGRSA organisms (Coleman et al., 1985). Chromosomally encoded resistance to tetracycline, penicillin, cadmium and mercury ions is also a feature of recent Australian MGRSA isolates (Lyon et al., 1983; Townsend et al., 1983; Gillespie et al., 1984), and resistance to these compounds is usually plasmid encoded in American and European strains (Lyon and Skurray, 1987).

A significant number of the Phenotype-III MGRSA strains expressed high-level resistance to ethidium bromide. This phenotypic marker was very unstable, and the location of the $\mathrm{Eb}^{\mathrm{h}}$ genetic determinant could not be ascribed to a plasmid by curing or transformation experiments, suggesting a possible chromosomal location, not previously reported in nosocomial MGRSA or MRSA isolates (Lyon and Skurray, 1987). In the endemic Dublin MGRSA strains, high level ethidium bromide resistance was a consistent feature, and was invariably encoded on penicillinase and other large plasmids (Coleman et al., 1985), a feature observed in MRSA and MGRSA strains from several countries (Lyon and Skurray, 1987). Large staphylococcal penicillinase plasmids worldwide tend to share extensive homology (Lyon and Skurray, 1987), often encode resistance to metal ions and ethidium bromide (Lyon and Skurray, 1987) and, in some instances, can integrate into the staphylococcal chromosome (Schwesinger and Novick, 1975; Pattee et al., 1977). It is possible that the Phenotype-III and Baghdad MGRSA strains acquired chromosomally encoded resistance to penicillin and metal ions, and high level ethidium bromide resistance in the case of a proportion of the Phenotype-III isolates, by integration of such a plasmid. The extensive homology detected in the chromosomal DNA sequences of representative Phenotype-III and Baghdad isolates, when probed with a large penicillinase plasmid, strongly supports this suggestion. Furthermore, the extent of the homology detected under the conditions of high stringency used in the hybridisation experiments cannot be accounted for solely by the presence of homologous chromosomally encoded resistance determinants, suggesting the presence of extensive related penicillinase-plasmid DNA sequences in the chromosomal DNA of the Dublin PhenotypeIII and related Baghdad isolates tested.

The plasmids of $2 \cdot 2 \mathrm{~kb}$, encoding low level $\mathrm{Eb}^{\mathrm{r}}$, are similar in size, and mediate the expression of $\mathrm{Eb}^{\mathrm{r}}$ at a level similar to that expressed by small $\mathrm{Eb}^{\mathrm{r}}$ plasmids detected in Australian, Italian and American clinical $S$. aureus strains (Emslie et al., 1986). The low incidence of detection of this plasmid in the Phenotype-III Dublin strains may reflect the lack of a suitable selective pressure for maintenance.

The Dublin Phenotype-III and Baghdad MGRSA isolates had several features in common with the endemic Dublin MGRSA strains with regard to gentamicin resistance $\left(\mathrm{Gm}^{\mathrm{r}}\right.$; Coleman $e t$ al., 1985). Of the representative isolates examined, all apparently expressed chromosomally-encoded $\mathrm{Gm}^{\mathrm{r}}$ and several different levels of resistance were expressed by the isolates. Gentamicin resistance in clinical $S$. aureus isolates from many centres is due to closely related $\mathrm{Gm}^{\mathrm{r}}$ determinants (Lyon and Skurray, 1987) and in the case of Australian strains is encoded by a transposable element Tn 4001 (Lyon et al., 1984; Gillespie et al., 1987). Studies have shown that representative Phenotype-I, -II, -III and Baghdad MGRSA isolates all harbour a $\mathrm{Gm}^{\mathrm{r}}$ determinant which is homologous with that of Tn4001, and in the case of the Phenotype-I and -II isolates tested, the determinant is located on a transposable element (Storrs et al., 1988). Thus, the different levels of expression of $\mathrm{Gm}^{\mathrm{r}}$ by individual isolates could be explained, in part, by the presence of a $\mathrm{Gm}^{\mathrm{r}}$ transposon in different chromosomal locations.

The results described in this study demonstrate that the novel Dublin isolates and the Baghdad isolates are closely related, as defined by identical plasmid content, identical experimental phage type, similar chromosomally encoded resistance determinants and similar chromosomal hybridisation patterns following hybridisation with a penicillinase plasmid probe, indicating that the novel Dublin isolates and the MGRSA and MRSA strains isolated in Baghdad very likely had a common origin. Because the Phenotype-III isolates are very similar to strains isolated in Baghdad in 1984, together with the fact that the first patient from whom the isolates were obtained in Dublin 
had been hospitalised in Baghdad a short time previously, we interpret this evidence to indicate spread of the Phenotype-III MGRSA organisms from Baghdad to Dublin.

\section{REFERENCES}

Blair J E, Williams R E O 1961 Phage typing of staphylococci. Bulletin of the World Health Organization 24: 771-784.

Cafferkey M T, Hone R, Falkiner F R, Keane C T, Pomeroy H 1983 Gentamicin and methicillin resistant Staphylococcus aureus in Dublin hospitals : clinical and laboratory studies. Journal of Medical Microbiology 16: 117-127.

Cafferkey M T et al. 1985 Methicillin-resistant Staphylococcus aureus in Dublin 1971-1984. Lancet 2: 705-708.

Chang S, Cohen S N 1979 High frequency transformation of Bacillus subtilis protoplasts by plasmid DNA. Molecular and General Genetics 168: 111-115.

Coleman D C, Foster T J 1981 Analysis of the reduction in expression of tetracycline resistance determined by transposon $\operatorname{Tn} 10$ in the multicopy state. Molecular and General Genetics 182: 171-177.

Coleman D C et al. 1985 Susceptibility to antimicrobial agents and analysis of plasmids in gentamicin- and methicillinresistant Staphylococcus aureus from Dublin hospitals. Journal of Medical Microbiology 20: 157-167.

Coleman D C, Arbuthnott J P, Pomeroy H M, Birkbeck T H $1986 a$ Cloning and expression in Escherichia coli and Staphylococcus aureus of the beta-lysin determinant from Staphylococcus aureus : evidence that bacteriophage conversion of beta-lysin activity is caused by insertional inactivation of the beta-lysin determinant. Microbial Pathogenesis 1: $549-564$

Coleman D C et al. 1986b Mechanisms of pathogenicity in multi-resistant Staphylococcus aureus. Journal of Hospital Infection 7 Suppl A : 29-35.

Dowd G, Cafferkey M, Dougan G 1983 Gentamicin and methicillin resistant Staphylococcus aureus in Dublin hospitals: molecular studies. Journal of Medical Microbiology 16: 129-138.

Emslie K R, Townsend D E, Grubb W B 1986 Isolation and characterisation of a family of small plasmids encoding resistance to nucleic acid-binding compounds in Staphylococcus aureus. Journal of Medical Microbiology 22: 9-15.

Gillespie M T, May J W, Skurray R A 1984 Antibiotic susceptibilities and plasmid profiles of nosocomial methicillin-resistant Staphylococcus aureus: a retrospective study. Journal of Medical Microbiology 17: 295-310.

Gillespie M T, Lyon B R, Messerotti L J, Skurray R A 1987 Chromosome-and plasmid-mediated gentamicin resistance in Staphylococcus aureus encoded by Tn4001. Journal of Medical Microbiology 24: 139-144.

Hone $\mathrm{R}$ et al. 1981 Bacteraemia in Dublin due to gentamicinresistant Staphylococcus aureus. Journal of Hospital Infection 2: $119-126$.
We acknowledge the support of the Irish Medical Research Council for a Hospital Infection Unit Programme grant and thank Mr B. F. Carey for useful discussion and assistance, Dr F. Falkiner for reviewing the work, and Miss J. M. Delaney for help in compiling the manuscript.

Kreiswirth B N et al. 1983 The toxic shock syndrome exotoxin structural gene is not detectably transmitted by a prophage. Nature 305: 709-712.

Lyon B R, May J W, Skurray R A 1983 Analysis of plasmids in nosocomial strains of multiple-antibiotic-resistant Staphylococcus aureus. Antimicrobial Agents and Chemotherapy 23 : 817-826.

Lyon B R, May J W, Skurray R A 1984 Tn4001: a gentamicin and kanamycin resistance transposon in Staphylococcus aureus. Molecular and General Genetics 193 : 554-556.

Lyon B R, Skurray R A 1987 Antimicrobial resistance of Staphylococcus aureus: genetic basis. Microbiological Reviews 51 : 88-134.

Maniatis T, Fritsch E F, Sambrook J 1982 Molecular cloning: a laboratory manual. Cold Spring Harbor, New York, pp 387-389.

Montgomery K, Raymundo L, Drew W L 1979 Chromogenic cephalosporin spot test to detect beta-lactamase in clinically significant bacteria. Journal of Clinical Microbiology 9: 205207.

Mulvey M, Arbuthnott J P, Coleman D C 1986 Molecular typing of methicillin and gentamicin resistant Staphylococcus aureus in Dublin. European Journal of Clinical Microbiology 5: 719-725.

Pattee P A, Thompson N E, Haubrich D, Novick R P 1977 Chromosomal map locations of integrated plasmids and related elements in Staphylococcus aureus. Plasmid 1: 38 51 .

Rigby P W J, Dieckmann M, Rhodes C, Berg P 1977 Labeling deoxyribonucleic acid to high specific activity in vitro by nick translation with DNA polymerase. International Journal of Molecular Biology 113 : 237-251.

Schwesinger M D, Novick R P 1975 Prophage-dependent plasmid integration in Staphylococcus aureus. Journal of Bacteriology 123 : 724-738.

Southern E M 1975 Detection of specific sequences among DNA fragments separated by gel electrophoresis. Journal of Molecular Biology 98 : 503-517.

Storrs M J, Courvalin P, Foster T J 1988 Genetic analysis of gentamicin resistance in methicillin- and gentamicinresistant strains of Staphylococcus aureus isolated in Dublin hospitals. Antimicrobial Agents and Chemotherapy 32: 1174 1181.

Townsend D E, Grubb W B, Ashdown N 1983 Genetics of drug resistance in methicillin-resistant Staphylococcus aureus from Australian hospitals. Journal of Hospital Infection 4 : 331-337.

Townsend D E et al. 1987 The international spread of methicillinresistant Staphylococcus aureus. Journal of Hospital Infection 9: $60-71$. 